\title{
Between Discretion and Proportionality: The Duty of Care in EU Judicial Review
}

Herwig C.H. Hofmann ${ }^{1}$

\section{Abstract:}

This article concentrates on the 'duty of care' or 'diligence', a principle that has become ubiquitous in CJEU case law due to its central role in calibrating the intensity of judicial review of EU acts on the legislative, regulatory and single-case decision-making levels. This article explores the development of the principle and critically reviews its use as well as whether it actually achieves the demands placed on it. The article further examines the tools developed and the emergence of the duty of care as a principle conferring individual rights in various procedural contexts. The article describes how the duty of care has become a central link between on the one hand, a separation of powers-inspired respect for discretion of the institutions and bodies of the EU and, on the other hand, ensuring a rule of law based effective review of the legality of acts - a central feature in the EU specific approach to developing proportionality.

$\underline{\text { Key words: }}$

EU public law - judicial review - discretion - proportionality - duty of care - diligence

Between Discretion and Proportionality: The Duty of Care in EU Judicial Review 1

1. Origins of Care as Information-Based Principle ............................................ 4

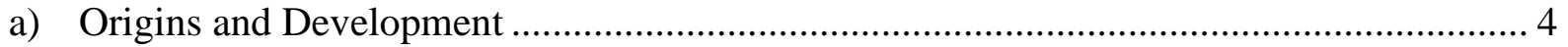

b) Care as a Concept of Judicial Review and a General Principle of EU Law .................. 7

c) Care as Review-Criteria in Regulatory and Legislative Acts ....................................... 9

d) Reasons for the Spread of the Duty of Care ........................................................ 11

2. Elements of the Duty of Care - Solving the Goldilocks Problem? ................................ 13

a) Factual Elements - Quantitative and Qualitative ........................................................ 13

b) Cognitive Elements of the Duty of Care Test....................................................... 16

3. The Role of Care in Judicial Review of Discretionary Decisions ............................... 18

1 Professor of European and Transnational Public Law, University of Luxembourg, Faculty of Law Economics and Finance. This article is also published, in slightly different form in the 2020 edition of the Review of European Administrative Law (REAL). 
a) The Duty of Care as Individual Right and Objective Criteria of Legality...................... 18

b) Care, Proportionality, Discretion and the Public Interest ........................................ 20

c) The Duty of Care in Codification of Procedures ...................................................... 25

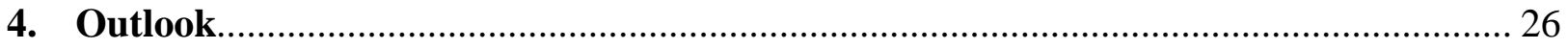

One of the central problems in establishing effective judicial remedies by EU courts is to find a balance between, on the one hand, a separation of powers-inspired respect for discretion of the institutions and bodies of the EU and, on the other hand, ensuring a rule of law based effective review of the legality of acts. This is a fundamental problem of any public law jurisdiction within a constitutionalised structure. ${ }^{2}$ More specifically, this article concentrates on the approach adopted by the Court of Justice of the European Union (CJEU) based on developing extensive case law on a little known - but highly versatile - legal principle: the 'duty of care', sometimes referred to as the duty of 'diligence' in English language versions of CJEU cases. ${ }^{3}$ Although ubiquitous in CJEU case law, the duty of care is not widely discussed or acknowledged for its central role in calibrating the intensity of judicial review of public action. ${ }^{4}$ Understanding the role of the specific emanation of the 'duty of care', as developed in today's CJEU case law, is a task complicated by the fact that notions of care and diligence in case law of the CJEU refer to various concepts. ${ }^{5}$ Some of these are related to the obligations of the EU as an employer requiring care for its personnel, sometimes also referred to as solicitude. ${ }^{6}$ Other

\footnotetext{
${ }^{2}$ See for a vivid example of the result of disagreements the German Constitutional Court's explicit expression of discontent with the CJEU's approach to review of proportionality leading to an ultra vires act in German Constitutional Court (Bundesverfassungsgericht) of 5 May 2020 joined cases 2 BvR 859/15, 2 BvR 1651/15, 2 BvR 2006/15, 2 BvR 980/16 PSPP, English version at https://www.bundesverfassungsgericht.de/SharedDocs/Entscheidungen/EN/2020/05/rs20200505_2bvr085915e n.html

3 For one example, see Case T-108/08 Davidoffv OHIM [2011] EU:T:2011:391, para 19. Sometimes, both care and diligence are used together. See e.g. Case T-204/03 Haladjian v Commission [2006] EU:T:2006:273, para 29: 'when the Commission decides to proceed with an investigation, it must ... conduct it with the requisite care, seriousness and diligence so as to be able to assess with full knowledge of the case the factual and legal particulars submitted for its appraisal by the complainants.'

4 This might have contributed to the lack of understanding of the EU legal order in the GCC's in PSPP cited in footnote 2.

${ }^{5}$ See, for an overview, Bucura Mihaescu, The right to good administration (Nomos 2015) 394-405 with many further references.

${ }^{6}$ Duties of 'solicitude' or 'care' in the context of EU staff cases are used as criteria to balance the reciprocal rights and obligations of the employer and the EU's staff: see e.g. Case C-321/85 Schwiering v Court of Auditors [1986]
} 
cases where the CJEU reviews breaches of the duty of care are used to identify criteria for damages. ${ }^{7}$ There is, however, a third category, mentioning notions of care with origins in some of the earliest decisions of the Court of Justice, which has become a central balancing tool in judicial review. The latter concept of the duty of care is the topic of this article. It has been developed as an essentially information-based concept by which the CJEU attempts to uphold a rule of law-based judicial review whilst at the same time respecting discretion of decision makers. ${ }^{8}$

This outlines the purpose of this article: it introduces and explores the notion of the duty of care and asks whether the tests developed by the Court serves to achieve the balancing objectives. The article does so by introducing, in its first part (1), the origins of the principle in the earliest case law of the CJEU, and the principle's re-emergence since the early 1990s. This part develops an understanding of its steady progress towards becoming near ubiquitous in the case law and examines the duty of care as a principle conferring individual rights in various procedural contexts. This exploratory part of the article will also look at which types of acts are reviewed under the duty of care, by screening various uses of the principle regarding single-case decision making by EU and Member States bodies acting in the scope of EU law as well as regulatory acts and legislative acts. Part (2) of the article then explores why the duty of care has spread into so many diverse aspects of review of acts: it asks for the purposes which the duty of care has been developed to serve, and analyses the relation between care and discretionary powers, the articulation of the public interests by public bodies and,

EU:C:1986:408, para 18. The CJEU obliges decisions concerning the situation of an official to be based on careful and impartial consideration of all the factors, especially taking into account not only the interests of the service, but also those of the official concerned: see e.g. Case T-203/97 Forvass v Commission [1999] EU:T:1999:135, para 3; Case C-181/03 P Nardone v Commission [2005] EU:C:2004:397, Opinion of AG Maduro, para 54).

${ }^{7}$ See, for example, Joined Cases T-198/95, T-171/96, T-230/97, T-174/98 and T-225/99 Comafrica v Commission [2001] EU:T:2001:184, para 144 establishing that 'the finding of an error or irregularity on the part of an institution is not sufficient in itself to attract the non-contractual liability of the Community unless that error or irregularity is characterized by a lack of diligence or care' (emphasis added). This goes back to early cases granting damages where bodies 'gravely neglected the duties of supervision required by a normal standard of care' (Joined Cases 19/60, 21/60, 2/61 and 3/61 Société Fives Lille Cailv High Authority [1961] EU:C:1961:22, 297) or where the bodies had displayed an obvious lack of care (Joined Cases 29/63, 31/63, 36/63, 39/63 to 47/63, 50/63 and 51/63 Providence and Others v High Authority [1965] EU:C:1966:29, 937).

${ }^{8}$ See, with further references, Herwig C H Hofmann, 'Inquisitorial Procedures and General Principles of Law: The Duty of Care in the Case Law of the European Court of Justice' in Laverne Jacobs (ed), The Nature of Inquisitorial Processes in Administrative Regimes: Global Perspectives (Ashgate 2013) 153-166; Bucura Mihaescu Evans, The right to good administration at the crossroads of the various sources of fundamental rights in the EU integrated administrative system (Nomos 2015) 392-426. 
importantly, the relation between care and proportionality review. The last part of the article (3) reviews whether the duty of care is a tool capable of fulfilling its purpose of undertaking the balancing between separation of powers and the control of legality, and between discretion and judicial review of proportionality. Is the duty of care the Goldilocks principle, allowing the Court to identify the sweet spot where the right balance between these principles can be found? On this basis, the article closes with some considerations on research questions to be asked in the context of the risks and rewards of applying the duty of care as an information based procedural principle to important matters of substantive justice.

\section{Origins of Care as Information-Based Principle}

The duty of care as an information-based principle, allowing for the balancing of various competing concepts of judicial accountability, has evolved from the early case law of the Court of Justice and is now a near ubiquitous feature of the CJEU's case law. This part outlines how it emerged in the earliest case law of the CJEU and was redeveloped since the 1990s (a) to being now recognised as granting individual rights (b). It further discusses some possible explanations for the spread of the principle throughout the case law of the CJEU (c).

\section{a) Origins and Development}

The origins of the approach to the definition of duty of care as a court-developed principle reach back into the 1955 case of Netherlands v High Authority. ${ }^{9}$ In the case, the CJEU identified criteria for reviewing the legality of a regulatory decision of the High Authority of the European Coal and Steel Community (ECSC). It saw the necessity to balance, on the one hand, the High Authority's discretion as to the definition of maximum prices for certain steel products under specific market conditions with, on the other hand, its mandate to undertake judicial review of the legality of the High Authority's act. The balance was achieved by today's

\footnotetext{
${ }^{9}$ Case 6/54 Netherlands v High Authority [1955] EU:C:1955:5, 112 (English language version) and 220 (French version). I thank Bucura Mihaescu Evans for having pointed out to me the origin of the duty of care in this case.
} 
familiar concept of 'strict review of compliance' by the High Authority, with essential procedural requirements formulated in provisions that intended to ensure that the measures concerned were formulated with all due care and prudence'. ${ }^{10}$ The 'due care and prudence' requirement led to two separate criteria: first, whether the High Authority had exercised care and prudence by collecting the relevant information by means of the studies and consultations required under the legal basis Article 61 ECSC. Second, cognitively the Court reviewed whether the findings of the studies substantiated the High Authority's decision. ${ }^{11}$ The Court therefore reviewed not only the information-base of the High Authority's decision, but also the act for consistency with the facts so established. This two-step approach to addressing the difficulties in combining, on the one hand, respect by the Court for the broad discretion granted to the High Authority with, on the other hand, the obligation of the Court to ensure effective judicial review, had been outlined in the opinion of Advocate General (AG) Roemer. In formulating what later would become the CJEU's Remia formula, ${ }^{12}$ the AG found that, where the High Authority enjoyed wide discretion, such could be subject only to limited reexamination by the Court but such discretion needed to be counter-balanced by strict adherence to the procedural requirements for the adoption of regulatory decisions. The latter included, under Article 61 ECSC, a 'particularly extensive duty of examination and consultation. ${ }^{13}$

In Netherlands v High Authority, the CJEU outlined the basic approach by which an act adopted by the High Authority exercising regulatory discretion could be annulled if the Court found non-compliance with procedural obligations for identifying which information - and from what source - should be collected and considered. Little remarked and almost forgotten, most of the literature dates the emergence of this principle to its re-discovery by the Courts in the

${ }^{10} \mathrm{Ibid}$. See, for later case law qualifying provisions in EU law requiring the gathering and allowing for real taking into account of all relevant information prior to decision-making as essential procedural requirements: Case C-644/17 Eurobolt [2019] EU:C:2019:555, paras 50-51; Case C-183/16 P Tilly-Sabco v Commission [2017] EU:C:2017:704, para 114 and Case C-263/95 Germany v Commission [1998] EU:C:1998:47.

11 Ibid.

${ }^{12}$ Case 42/84 Remia v Commission [1985] EU:C:1985:327, para 34, stating in summary under what is now known as the 'Remia formula': that the CJEU will limit judicial review of discretionary powers to verifying compliance with the relevant procedural rules, adequate reasoning and whether the act is beset by manifest errors of appraisal and whether there has been a 'misuse of powers'.

${ }^{13}$ Case 6/54 Netherlands v High Authority [1955] EU:C:1955:1, Opinion of AG Roemer, 133. 
early 1990s, where the notion of care became more widely acknowledged as a principle of EU law and more broadly discussed following the CJEU's 1991 TU München ${ }^{14}$ and Nölle cases. ${ }^{15}$ The case of the technical university of Munich - TU München - developed the formula for identifying the duty of care as the 'the duty of the competent institution to examine carefully and impartially all the relevant aspects of the individual case ${ }^{16}$ prior to decision making. Nölle confirmed compliance with the duty of care as an individual right following from a clear, precise and unconditional obligation of the public decision maker. Review of discretion, it was set out in Technische Universität München, ${ }^{17}$ requires compliance with procedural rights and obligations. The more discretion a decision maker has, the 'more fundamental importance'18 compliance with procedural obligations takes in order to ensure effective judicial review. Both TU München and Nölle confirmed the status of the duty of care as an essential procedural requirement in that the failure to comply with the obligations of the duty of care may lead such act to being declared void. ${ }^{19}$

The emergence in the 1990s of the duty of care in single-case decision making coincides with controlling administrative discretion of EU institutions and bodies: the development of EU law had advanced. Decision making in certain policy areas such as customs (TU München) and anti-dumping (Nölle) had become more frequent, with increasing direct effect on individual rights. Individuals had the possibility of seeking review of decisions concerning technical discretion. In order to ensure legitimacy of its review procedures, the CJEU then linked the duty of care to procedural principles - such as the right to a fair hearing, as in the TU München case - and required the institutions to not just hear, but also to reflect in its decision making the points raised by the parties.

\footnotetext{
${ }^{14}$ Case C-269/90 Technische Universität München v Hauptzollamt München-Mitte [1991] EU:C:1991:438.

15 See, especially, Case C-16/90 Eugen Nölle v Hauptzollamt Bremen_Freihafen [1991] EU:C:1991:233, Opinion of AG Van Gerven, para 28. An in-depth but pre-CFR assessment is given by Hanns Peter Nehl, Principles of Administrative Procedure in EC Law (Hart 1999) 104-65. For a thorough discussion in various contexts of the notion of care, diligence and solicitude in the case law of the CJEU in relation to principles of good administration, rights to damages and personnel matters, see Bucura Mihaescu Evans, The right to good administration at the crossroads of the various sources of fundamental rights in the EU integrated administrative system (Nomos 2015) 392-426.

${ }^{16}$ Case C-269/90 Technische Universität München v Hauptøollamt München-Mitte [1991] EU:C:1991:438, para. 14.

${ }^{17}$ Case C-269/90 Technische Universität München v Hauptzollamt München-Mitte [1991] EU:C:1991:438.

18 Ibid.

${ }^{19}$ See e.g. Case 6/54 Netherlands v High Authority [1955] EU:C:1955:5 and Case C-338/10 GLS [2012] EU:C:2012:158, paras 34 and 36-37.
} 


\section{b) Care as a Concept of Judicial Review and a General Principle of EU Law}

TU München and Nölle thus show an individual rights-based development which the case Netherlands $v$ High Authority necessarily lacked, having been brought by a Member State. Therefore, while the 1955 case concerned a 'regulatory act' of general application, the cases from the 1990s concerned single case decision making and challenges to those acts brought by individuals. Accordingly, these cases focussed on individual rights of the plaintiffs. Importantly, therefore, the General Court held in Nölle that the principle of care constitutes 'a rule protecting individuals'. ${ }^{20}$ Since then, the case law of the CJEU has developed to understand the principle of care as an 'inherent' sub-component to the right to good administration as also formulated in Article 41 of the Charter ${ }^{21}$ and, more generally, the principle of sound administration. ${ }^{22}$ Despite its initial hesitations in max.mobil, ${ }^{23}$ the CJEU case law thereby has acknowledged the status of the duty of care as being protected amongst the general principles of EU law. ${ }^{24}$ This recognition is not only relevant for actions of annulment

\footnotetext{
${ }^{20}$ Case T-167/94 Nölle v Council and Commission [1995] EU:T:1995:169, para 76.

${ }^{21}$ See e.g. Case C-47/07 P Masdar (UK) Ltd v Commission [2008] EU:C:2008:726, para 92: 'That duty of care is inherent in the principle of sound administration.'; Case C-556/14 P Holcim (Romania) SA v European Commission [2016] EU:C:2016:207, para 80: 'It must be noted, first of all, that, in accordance with the principle of sound administration, the EU institutions must examine all the relevant particulars of a case with care and impartiality and gather all the factual and legal information necessary to exercise their discretion' (making further reference to Case C-534/10 P Brookfield New Zealand and Elaris v CPVO [2012] EU:C:2012:813, para 51) and Case C-337/15 P European Ombudsman $v$ Claire Staelen [2017] EU:C:2017:256, para 34: 'It must also be borne in mind that the duty to act diligently which is inherent in the principle of sound administration and applies generally to the actions of the EU administration in its relations with the public requires that that administration act with care and caution.' See also, for the General Court, e.g. Case T-286/09 Intel Corp. $v$ Commission [2014] EU:T:2014:547, para 359: 'In that regard, it should be noted that the guarantees afforded by the European Union legal order in administrative proceedings include, in particular, the principle of sound administration, enshrined in Article 41 of the Charter of Fundamental Rights, which entails the duty of the competent institution to examine carefully and impartially all the relevant aspects of the individual case' with reference to Joined Cases T-191/98, T-212/98 to T-214/98 Atlantic Container Line and Others v Commission [2003] EU:T:2003:245, para 404 and the case-law cited therein.

${ }^{22}$ Case C-47/07 P Masdar (UK) Ltd v Commission [2008] EU:C:2008:726, para 92.

${ }^{23}$ See especially the Court of Justice's appeal decision in the max.mobil case, in which it overturned the General Court's assessment of the obligation of 'diligent and impartial treatment of a complaint is associated with the right to sound administration which is one of the general principles that are observed in a State governed by the rule of law and are common to the constitutional traditions of the Member States' (Case T-54/99 max.mobil v Commission [2002] EU:T:2002:20, para 48) in Case C-141/02 P Commission v max-mobil [2005] EU:C:2005:98, paras 68-75.

${ }^{24}$ See e.g. Case C-337/15 P European Ombudsman v Claire Stehlen [2017] EU:C:2017:256, para 34; Case C-556/14 P Holcim (Romania) SA v European Commission [2016] EU:C:2016:207, para 80; Case C-534/10 P Brookfield New Zealand and Elaris v CPVO [2012] EU:C:2012:813, para 51 and Case T-326/07 Cheminova and others v Commission [2009] EU:T:2009:299, para 228.
} 
but also for damages claims. As the case Staelen illustrates, the CJEU explicitly finds that the 'duty to act diligently, which is inherent in the principle of sound administration', is a right intended to protect individuals which can - in principle - give rise to damage claims if violated. ${ }^{25}$

Today, the amount of cases concerning the duty of care has led observers to state that care has become the core and essence of good administration ${ }^{26}$ - an observation which in turn has led to the criticism that the notion of good administration has become 'often tautological of the principle of care'. ${ }^{27}$ The latter criticism, in my view, risks overstating the duty of care's role in view of the many other sub-principles within the umbrella concept of good administration, including those indicatively enumerated in Article 41(2) Charter of Fundamental Rights of the European Union (CFR). ${ }^{28}$

However, one important effect of the qualification of the duty of care as an inherent component of the general principles of good administration, and of defence rights protected as general principles of EU law, is its applicability to review the legality of acts of Member States when acting in the scope of EU law. ${ }^{29}$ For example, in Mukarubega, ${ }^{30}$ the CJEU recalled that the Member States were under the obligation to comply with general principles of EU law when taking decisions in the scope of EU law. Therefore, they are also under the obligation to 'examin[e] carefully and impartially all the relevant aspects of the individual case' and reason their decisions accordingly. ${ }^{31}$ Further, the CJEU requires Member States to protect the duty of care in the context of the principle of effectiveness of EU law and also as an individual right under EU law, for the protection of which Member States must provide effective judicial

${ }^{25}$ Case C-337/15 P European Ombudsman v Claire Stehlen [2017] EU:C:2017:256, para 34.

${ }^{26}$ See e.g. Julie Dupont Lassale, Le Principe de Bonne Administration en Droit de l'Union Européenne (Bruylandt 2013) 92.

${ }^{27}$ Hanns Peter Nehl, 'Good administration as procedural right and/or general principle?' in Herwig C H Hofmann and Alexander H Türk (eds), Legal Challenges in EU Administrative Law (Edward Elgar 2009) 322-351, at 350.

${ }^{28}$ Jacques Ziller, Droit à une Bonne Administration (Juriclasseur Libertés 2007) 7-8.

${ }_{29}$ The result is that, while the right to good administration under Article 41 CFR is addressed only to EU institutions, bodies, offices and agencies as a general principle of law under Article 6(3) TEU, the duty of care is also applicable to Member States acting in the scope of EU law. See Herwig C H Hofmann and Bucura Mihaescu, 'The Relation between the Charter's Fundamental Rights and the Unwritten General Principles of EU Law - Good Administration as the 'Test-Case' (2013) 9 European Constitutional Law Review 73.

${ }^{30}$ Case C-166/13 Sophie Mukarubega v Préfet de police, Préfet de la Seine-Saint-Denis [2014] EU:C:2014:2336.

${ }^{31}$ Ibid, para 48 with reference to Case C-269/90 Technische Universität München [1991] EU:C:1991:438, para 14 and Case C-349/07 Sopropé [2008] EU:C:2008:746, para 50. 
remedies (Article $47 \mathrm{CFR}$ ). One example for the latter approach is Schrems $I^{32}$ in which the CJEU required that a Member State body must comply with its obligations to act 'with all due diligence' when acting within the scope of the powers conferred to it by EU law. ${ }^{33}$

\section{c) Care as Review-Criteria in Regulatory and Legislative Acts}

The principle of care defined as a part of defence rights protected as general principles of EU law and as being inherent to good administration does not limit the duty of care to single-case decision making. According to the case law of the CJEU, the duty of care is a principle which is equally applicable in the review of acts of general application. ${ }^{34}$ Not coincidentally was the very first case of the CJEU addressing the duty of care a case in which an act of general, normative content was subject to review: Netherlands v High Authority of 1955, in fact, concerned general regulatory powers under Article 61 ECSC. Since then, the CJEU has consistently applied the duty of care to review acts of regulatory nature in the context of actions for annulment brought by individual companies. Examples include cases in the area of monetary policy, ${ }^{35}$ anti-dumping cases, ${ }^{36}$ and cases in the context of the regulation of the Common Agriculture Policy. ${ }^{37}$ Especially in risk-regulation matters, the duty of care has been applied as a criteria of review for acts of general application with respect to plant-protection

32 Case C-362/14 Schrems v DPC [2015] EU:C:2015:650.

33 Case C-362/14 Schrems v DPC [2015] EU:C:2015:650, para 63.

${ }^{34}$ Dominque Ritleng, 'Judicial Review of EU Administrative Discretion: How Far Does the Separation of Powers Matter?' in Joana Mendes and Ingo Venzke, Allocating Authority: Who Should Do What in European and International Law? (Bloomsbury 2018) 183-216.

35 See e.g. Case C-62/14 Gauweiler and Others v Deutscher Bundestag [2015] EU:C:2015:400, para 69 (regarding an ECB purchase programme to be implemented by individual acts under Article 18 of the ESCB Statutes) and Case T333/10 Animal Trading Company (ATC) and Others v Commission [2013] EU:C:2013:451, paras 84-94 (concerning a general decision by the Commission addressed at the Member States which had negative effects on the plaintiffs). See also Joana Mendes, 'Discretion, Care and Public Interests in the EU Administration: Probing the Limits of Law' in Herwig C H Hofmann and Jacques Ziller (eds), Accountability in the EU - The Role of the European Ombudsman (Edward Elgar 2017) 156.

${ }^{36}$ See Joined Cases C-191/09 P and C-200/09 P Councilv Interpipe Niko Tube and Interpipe NTRP [2012] EU:C:2012:78, para 113.

${ }^{37}$ See Case T-285/03 Agraz and others v Commission [2005] EU:T:2005:109, at para. 49. 
products, ${ }^{38}$ additives in animal foods, ${ }^{39}$ and, more generally, the regulation of dangerous substances. ${ }^{40}$

Concepts underlying the duty of care are also present in the Court's case law on the review of acts of a legislative nature. Examples for this approach arose in the Luxembourg Airport and Vodafone cases ${ }^{41}$ where the CJEU reviewed questions on the legality of legislative acts in view of whether, in the exercise of legislative discretion, all relevant factors necessary under the proportionality review had been considered. ${ }^{42}$ This approach was confirmed in Poland $v$ EP and Councilt3 of 2019, where the Court found that a properly conducted legislative impact assessment report may serve as indication that the institutions had exercised their legislative discretion taking into account the available scientific data and information. ${ }^{44}$ The relevance of the concept of 'care' as the obligation to collect and take into account all relevant facts and interests prior to decision making is also subject to obligations in the 2016 Interinstitutional Agreement on Better Law-Making, ${ }^{45}$ which requires the Commission to conduct an impact assessment on legislative and non-legislative initiatives in cases where a planned EU legal act is likely to have significant impact. ${ }^{46}$

38 See Case T-475/07 Dow AgroSciences and others v Commission [2011] EU:T:2011:445, para 154.

39 See Case T-13/99 Pfizer Animal Health v Council [2002] EU:T:2002:209, para 171 and Case T-70/99 Alpharma v Council [2002] EU:T:2002:210, para 182.

40 See Case C-425/08 Enviro Tech (Europe) [2009] EU:C:2009:635, para 62 and Case T-369/03 Arizona Chemical and others v Commission [2005] EU:T:2005:458, para 85.

${ }^{41}$ Case C-176/09 Luxembourg v EP and Council [2011] EU:C:2011:290, para 65 and Case C-58/08 Vodafone and Others [2010] EU:C:2010:321, para 55.

42 This approach was highlighted as the leading model of review by Koen Lenaerts, writing extra-judicially in Koen Lenaerts, The European Court of Justice and Process-oriented Review, College of Europe, Department of European Legal Studies, Research Paper in Law 01/2012.

43 Case C-128/17 Poland v European Parliament and Council [2019] EU:C:2019:194.

$44 \mathrm{Ibid}$, paras 45, 100, 136. See, in broader terms and including questions of systematised information gathering through impact assessments in judicial review: Alberto Alemanno, 'Impact Assessment before Courts' in Claudio Radaelli and Claire Dunlop (eds), Handbook of Regulatory Impact Assessment (Edward Elgar 2016) 127-141.

45 Interinstitutional Agreement between the European Parliament, the Council of the EU and the European Commission of 13 April 2016 on Better Law-Making [2016] OJ L123/1.

$46 \mathrm{Ibid}$, stating in point 12: 'Impact assessments are a tool to help the three Institutions reach well-informed decisions (...) . Impact assessments should cover the existence, scale and consequences of a problem and the question whether or not Union action is needed. They should map out alternative solutions and, where possible, potential short and longterm costs and benefits, assessing the economic, environmental and social impacts in an integrated and balanced way and using both qualitative and quantitative analyses. (...) Impact assessments should be based on accurate, objective and complete information and should be proportionate as regards their scope and focus.' 


\section{d) Reasons for the Spread of the Duty of Care}

The overview above on the duty of care shows that it is a principle with roots in the very earliest case law of the CJEU. The duty of care contains a now widely applied concept which can be traced across types of act, and which is applicable from single-case decision making by EU institutions and Member State bodies to regulatory acts of general content and legislative acts of the Union. Although, due to issues of terminology across different language versions, it can be difficult to trace the spread of the principle, in the different contexts the duty of care - single-case decision making, regulatory acts or legislative acts - is applied to serve the same basic requirements of the EU's legal system. It is designed to ensure that competing requirements of, on the one hand, exercising judicial review with the necessary restraint in view of discretionary powers conferred on the executive or legislative branches of powers and, on the other hand, upholding effective judicial protection, can be balanced. The importance of this distinction is rooted in the very constitutional basis of the Union: ensuring such effective judicial review is, in the words of the Court of Justice, one of the essential components of a system under the rule of law. ${ }^{47}$ Upholding the separation of powers-inspired concept of 'institutional balance', contrastingly, is a principle central to the legal system of the EU. Having one basic concept to structure this balancing process strengthens the coherence of the constitutional system of the EU, and makes the conditions under which review takes place less prone to specificities of each individual policy area. The duty of care could thus develop as a background procedural principle to provide a meta-principle for the review process of the procedural legality of acts.

Another factor which might contribute to explaining the spread of the duty of care as a legal principle in EU law, especially since the 1990s, is the deepening of legal integration and the increase in legal review of EU acts used to implement EU law. In the 1990s, much focus was placed on studying the effectiveness of EU law and its implementation in various contexts. In this phase, the necessity for an EU-specific approach might have become increasingly relevant.

\footnotetext{
${ }^{47}$ Case C-72/15 Rosneft [2017] EU:C:2017:236, para 73; Case C-362/14 Schrems I [2015] EU:C:2015:650, para 95 and Case C-562/13 Abdida [2014] EU:C:2014:2453, para 45.
} 
At the same time, EU law was becoming increasingly aware on matters of transparency of decision making. The latter includes the questions of information and informational input into decision making. Review thereof, however, risked requiring a limitation on the traditionally broad notion of discretion applied in EU law. The latter, based on a technocratic vision of broad socio-economic discretion conferred on the institutions, had the effect of shielding acts of EU institutions and bodies from detailed judicial review. Later, increasing sensitivity towards the protection of individual rights in view of regulatory powers of the EU and towards the growing relevance of proportionality-based review of rights heightened the need for a formula to balance these various requirements.

In this context, the duty of care appears to be using the tool of procedural review, allowing the Court to abstain neither from proportionality review nor from the respect for the conferral of discretion on EU institutions and bodies. An additional factor for the explicit formulation of the duty of care in EU law might have been furthered by the diverging approaches of various Member States to the protection of procedural principles. By explicitly outlining its principle of care, the CJEU identifies procedural rights as enforceable institutional obligations.; therefore, the CJEU's position as to procedural rights is made clear in contrast to some trends in the Member States. Germany, for example, despite respecting the 'Sorgfaltsgrundsatz', had enacted legislation barring administrative courts from annulling administrative acts in cases where the violation of procedural provisions would have no effect on the substantive content of the final act. Under German law, this exclusion also applies to acts with administrative discretion..$^{48}$ The approach of the CJEU under the duty of care can thus be understood as an explicit statement of a significantly higher procedural protection offered in EU law, more in

\footnotetext{
48 \4 of the German administrative procedure act (Verwaltungsverfahrensgesetz, VwVfG). Despite criticism in the legal literature, this legislation has been upheld by the highest administrative court, the Bundesverwaltungsgericht (BVerwGE 70, 143, 147) which did not question the constitutionality of the provision and allowed for review concentrated on substantive grounds. Judicial review of violations of procedural provisions are relegated to review by declaratory action irrespective of the validity of the administrative act beset by the procedural irregularities. See, with further references, Stelkens, Bonk and Sachs (eds) Verwaltungsverfahrensgesetz (9th edn, Beck 2018) \ 46 paras 5-6.
} 
line with the higher level of protection offered in some national legal orders ${ }^{49}$ - such as guaranteed in the Finnish Constitution, ${ }^{50}$ as well as national Administrative Procedural Acts. ${ }^{51}$ In view of these discussions on the development, use, and possible motivation for development of the duty of care, the question arises whether the principle can achieve the task for which it has been deployed. The question is: can the proceduralisation of review do justice to both notions of respect for discretion and proportionality review as required by EU law not only for limitations of fundamental rights?

\section{Elements of the Duty of Care - Solving the Goldilocks Problem?}

The discussion of the scope and role of the duty of care raises two questions, firstly whether the duty of care's procedural criteria can support the exercise of balancing requirements between discretion and proportionality. Secondly, do they allow reaching a 'sweet-spot' between too much discretionary leeway or too overburdening judicial review replacing decision making? Netherlands v High Authority had already introduced two separate aspects to be revisited in this part: here, section (a) looks at the factual elements of care and (b) at the cognitive requirements of reviewing whether the information collected sustains the decision.

\section{a) Factual Elements - Quantitative and Qualitative}

A central feature of the duty of care has been its use as a tool to revise the factual bases of decisions. ${ }^{52}$ The facts-related approach consists of a set of obligations identifying two aspects of the information to be taken into account in decision making. Quantitatively, criteria exist as to which amount of information should be collected prior to decision-making; qualitatively, the

\footnotetext{
49 See, for some further considerations, the comparative studies prepared for the Seminar of the Association of High Administrative Courts and Conseils d'Etat (ACA-Europe) in Cologne, 2-4 December 2018.

50 See e.g. Section 21 of the Constitution of Finland, of 11 June 1999 (731/1999, amendments up to 1112 / 2011 included).

51 See e.g. Section 3.2. (entitled "Duty of care and weighting of interests") of the Dutch General Administrative Law Act (Algemene Wet Bestuursrecht), AWB of June 4, 1992, Staatblad, 1992, 315.

52 Joana Mendes, 'Discretion, Care and Public Interests in the EU Administration: Probing the Limits of Law' in Herwig C H Hofmann and Jacques Ziller (eds), Accountability in the EU - The Role of the European Ombudsman (Edward Elgar Publishing 2017) 156.
} 
test defines of which nature and from which source such information should arise. Both elements of the information collection are related to the investigatory concept underlying EU public decision-making procedures, under which all relevant facts of a decision-making procedure must be assembled by the decision maker. ${ }^{53}$

The quantitative element of the obligations defined by the CJEU under the duty of care requires the collection and examination of all relevant aspects ${ }^{54}$ of a case which may have a bearing on the adoption of a measure, ${ }^{55}$ including in cases where the decision maker has discretion. ${ }^{56}$ According to the CJEU in Tetra Laval, the decision maker must especially analyse 'all the information which must be taken into account in order to assess a complex situation'. ${ }^{7}$ The notion of 'relevance' can either arise from explicit obligations listed in the legal basis of an act or may arise from general principles of EU law or from Treaty provisions, including non-policy specific 'horizontal clauses'. ${ }^{58}$ Under the investigatory principle, a decision maker may not necessarily limit an investigation to the information provided by individual parties in the investigation, ${ }^{59}$ but has the obligation to examine also 'matters not expressly raised' by parties to a procedure, ${ }^{60}$ and the decision maker may be expected to have access to. ${ }^{61}$ The obligation to investigate under the duty of care also requires acquiring knowledge about

\footnotetext{
${ }^{53}$ Case C-367/95 P Commission v Sytraval and Brinks France [1998] EU:C:1998:154, para 60, 62 (referring also to the obligation to take into account ex officio also matters not expressly raised by parties to a procedure).

${ }^{54}$ Case C-269/90 Technische Universität München v Hauptzollamt München-Mitte [1991] EU:C:1991:438.

55 Case C-408/04 P Commission v Salzitter [2008] EU:C:2007:491, Opinion of AG Bot, para 265.

56 Case C-405/07 P Netherlands v Commission [2008] EU:C:2008:613, para 56: 'where a Community institution has a wide discretion, the review of observance of guarantees conferred by the Community legal order in administrative procedures is of fundamental importance. The Court of Justice has had occasion to specify that those guarantees include, in particular for the competent institution, the obligations to examine carefully and impartially all the relevant elements of the individual case and to give an adequate statement of the reasons for its decision (see Case C-269/90 Technische Universität München [1991] ECR I-5469, paragraph 14; Joined Cases C-258/90 and C-259/90 Pesquerias De Bermeo and Naviera Laida v Commission [1992] ECR I-2901, paragraph 26; and Spain v Lenzing, paragraph 58)'.

57 Case C-12/03 P Commission v Tetra Laval [2005] EU:C:2005:87, para 39.

58 See e.g. Article 11 TFEU, which requires that 'environmental protection requirements . . . be integrated into the definition and implementation of the Union policies and activities, in particular with a view to promoting sustainable development' or Article 168(1) first paragraph TFEU, which requires that 'a high level of human health protection . . . be ensured in the definition and implementation of all Union policies and activities'. See, in that respect, the findings of the General Court in e.g. Case T-13/99 Pfizer Animal Health v Council [2002] EU:T:2002:209, para 158.

59 See Case C-338/10 GLS [2011] EU:C:2011:636, Opinion of AG Bot, paras 98ff.

${ }^{60}$ Case C-367/95 P Commission v Sytraval and Brinks France [1998] EU:C:1998:154, paras 60, 62 - linking this duty to the principle of sound or good administration.

${ }^{61}$ See Case C-338/10 GLS [2011] EU:C:2011:636, Opinion of AG Bot, paras 103-105 - referring to relevant statistics published by Eurostat.
} 
individual interests potentially affected by a decision under the 'obligation to obtain all the necessary points of view'. ${ }^{62}$

These elements of the duty of care are not only applicable to information which is explicitly listed in positive law to be collected: the obligation also exists where a decision maker has discretion as to the methods of collecting information for decision making. Discretion regarding the decisional outcome can, however, only be properly based on a complete understanding of relevant factors. The effect of the quantitative element of the duty of care is thus strongly linked to reviewing the input into discretionary decision making.

In addition to the quantitative element of the duty of care obliging a decision maker to rely on 'the most complete' information, the duty of care also has a qualitative element consisting of the obligation for a decision maker to base decision making on the most 'reliable information possible'. ${ }^{63}$ The notion of reliability is defined by the nature of the source and the type of procedure used to obtain the information. This might include the requirement of obtaining scientific expertise for decision making, irrespective of whether such is explicitly or implicitly required in the legal basis of a decision. ${ }^{64}$

The qualitative obligation to have recourse to expertise had already been at the heart of the development of the duty of care in the seminal cases. For instance, Netherlands v High Authority addressed the need to conduct studies, inter alia about pricing in certain markets prior to taking a decision as to maximum prices in the steel industry. The obligation to seek expertise was further spelt out in TU München, and has been reconfirmed in subsequent case law. ${ }^{65}$ Under this case law, even in the absence of a statutory requirement, the duty of care obliges a decision maker to consult external scientific expertise where sufficient knowledge is not available inhouse, and where such proves necessary for the collection of all necessary information. ${ }^{66}$ In risk-regulation matters, the CJEU quite broadly states that, under the duty of care, 'the

${ }^{62}$ Case T-369/06 Holland Malt v Commission [2009] EU:T:2009:319, para 195.

${ }^{63}$ Case C-525/04 P Spain v Lenæing [2007] EU:C:2007:698, para 57.

${ }^{64}$ Reference to independent scientific expertise may, in certain cases, be protected in the framework of fundamental rights, especially the right to a fair hearing: see e.g. Case C-276/01 Steffensen [2003] EU:C:2003:228, paras 73, 80.

${ }_{65}^{65}$ See e.g. Case C-439/05 P and C-454/05 P Land Oberösterreich and Austria v Commission [2007] EU:C:2007:510, para 32.

${ }^{66}$ Case C-269/90 Technische Universität München v Hauptrollamt München-Mitte [1991] EU:C:2009:438; Case C-212/91 Angelopharm [1994] EU:C:1994:21 and Case C-405/07 P Netherlands v Commission [2008] EU:C:2008:613, paras 56 and 67. 
Commission is, as a rule, obliged to take account, in its decisions in the field of the environment, of all new scientific and technical data'. ${ }^{67}$ This implies that the institutions 'ensure that their decisions are taken in the light of the best scientific information available and that they are based on the most recent results of international research', ${ }^{68}$ an obligation the General Court explicitly links to compliance with the rule of law. ${ }^{69}$

Together, the quantitative and the qualitative element of the duty of care ensure that the decision maker will have at its disposal, in the words of the CJEU, the most complete 'factually accurate, reliable and consistent ${ }^{70}$ information possible. ${ }^{71}$ By invoking the rule of law to justify its requirements of collection of quality information-input into decision making, the Court increases the review of the exercise of powers, linking the avoidance of arbitrary decision making with requirements of necessity based not on decision makers' beliefs, but on reviewable facts. These are factors ensuring also impartiality of the administration and informed decision making of a legislature.

\section{b) Cognitive Elements of the Duty of Care Test}

The duty of care has, additionally, a cognitive element, by asking which information has been considered in reaching the decision to adopt an act and whether that act can logically be based on the information it relies on. The objective to examine and scrutinize, carefully and impartially, ${ }^{72}$ the aspects of a case in order to make a finding in full knowledge of all the facts relevant at the time of adoption'73 ensures a link between the factual basis collected during the investigation and preparation of an act and the final decision. Fulfilling these requirements

\footnotetext{
${ }^{67}$ Case C-405/07 P Netherlands v Commission [2008] EU:C:2008:613, paras 56 and 61.

${ }^{68}$ Case T-326/99 Fern Olivieri v Commission [2003] EU:T:2003:351, para 68; Case T-13/99 Pfizer Animal Health v Council [2002] EU:T:2002:209, para 158 and Case T-70/99 Alpharma v Council [2002] EU:T:2002:210, para 171. This approach is in compliance with Art 114 TFEU (Art 95(3) EC), which obliges the Commission, in the case of legislative proposals in these matters, to take into 'account in particular any new development based on scientific facts'.

${ }^{69}$ Case T-13/99 Pfizer Animal Healthv Council [2002] EU:T:2002:209, para 172 and Case T-70/99 Alpharma v Council [2002] EU:T:2002:210, para 183.

70 Case C-525/04 P Spain v Lenzing [2007] EU:C:2007:698, para 57.

${ }^{71}$ Case C-290/07 P Commission v Scott [2010] EU:C:2010:480, para 90.

72 Case C-269/90 Technische Universität München v Hauptzollamt München-Mitte [1991] EU:C:1991:438 and Case C-16/90 Nölle $v$ Hauptrollamt Bremen-Freihafen (Nölle I) [1991] EU:C:1991:402, para 29.

${ }^{73}$ Case C-367/95 P Sytraval [1998] EU:C:1998:154, para 60, 62 - referring also to the obligation to take into account ex officio also matters not expressly raised by parties to a procedure.
} 
requires judicial review beyond a mere plausibility-test, in that a Court needs to be satisfied that the facts established by the decision-maker are actually 'capable of substantiating the conclusions ${ }^{74}$ and thus sustain the decision taken. The test is how, cognitively speaking, the information collected in a decision making procedure was considered in the outcome, the final act. This test has been conducted by the Court since Netherlands v High Authority, where the CJEU controlled whether a decision maker could have drawn the decision from its own findings of facts. ${ }^{75}$ The cognitive part of the test conducted in review of the duty of care, therefore, is very much at the heart of decision making. The Courts review this requirement by scrutinising whether a decision is de facto compatible with the facts evoked either in the operational part of an act or within its reasoning. Prohibiting in-compatibilities between underlying facts and real-life acts has a central function within a system under the rule of preventing arbitrariness of decision-making. Therefore, beyond plausibility, the CJEU looks for a de facto possibility to base a decision on the collected facts.

Therefore, this element of the duty of care can be potentially regarded to be the one linked the closest with controlling discretionary powers under the principle of proportionality. Under the CJEU's three step proportionality test, the appropriateness of an act is ensured where the decision maker can show that the information collected supports that the outcome will be suitable for achieving a legislative objective. The cognitive element of the duty of care also plays an important role in reviewing whether, in the presence of several appropriate approaches to achieving a legislative objective, the approach chosen was the one limiting competing rights or public interests the least. The comparative nature of this second level of the proportionality test can turn out to be particularly fact intensive: competing scenarios must be investigated and evaluated. Given that the intensity of judicial review on the substance of the outcome has to be limited in view of potential discretion of a decision maker, transparency as to the information on which the balancing was based and as to the balancing process is an essential procedural tool. The latter allows respect for the decision-maker's choices within legal limits, whilst, at the same time, allowing for an in-depth judicial review.

\footnotetext{
${ }^{74}$ Case C-12/03 P Commission v Tetra Laval [2005] EU:C:2005:87, para 39.

${ }^{75}$ Case 6/54 Netherlands v High Authority [1955] EU:C:1955:5, 112 (English language version) and 220 (French version).
} 


\section{The Role of Care in Judicial Review of Discretionary Decisions}

The discussion under the second part of this article shows that, in judicial review, the duty of care serves as a principle to 'calibrate' the intensity of oversight. In this context, two basic questions arise, one, addressed below in a) concerns the question of the nature of the duty of care as an individual right and an 'objective' criteria of legality. The second, addressed below in b) concerns the notion of balancing of interests and the role of the public interest therein. The latter is an issue which has come to great prominence recently with the German Constitutional Court's (GCC) ruling on the European Central Bank's (ECB) PSPP programme. These discussions, it is argued below under c) explain also the increasing importance of the duty of care in core interinstitutional agreements and drafts for an EU regulation on administrative procedures.

\section{a) The Duty of Care as Individual Right and Objective Criteria of Legality}

The status of 'care' as one of the general principles of EU law 'inherent' ${ }^{76}$ in the principles of good administration and amongst rights of defence leads inter alia to the conclusion that the duty of care conferring individual rights in the sense of Article 47 CFR. ${ }^{77}$ Nonetheless, some formulations in the case law of the General Court (GC), notably in Arizona Chemical, in which the GC stated that care constituted 'essentially an objective procedural guarantee', ${ }^{78}$ might give rise whether care is an individual right only in the context of single case decision-making. Is the same also true in the context of regulatory acts of general content? Upon close review of the case law, it would appear that the notion of an 'objective' guarantee is not used in opposition to the notion of care as an 'individual right'. The GC used the word 'objective' guarantee in the context of the General Court reviewing standing requirements of an individual

\footnotetext{
${ }^{76}$ See e.g. Case C-47/07 P Masdar (UK) Ltd v Commission [2008] EU:C:2008:726, para 92.

77 See e.g. Case C-337/15 P European Ombudsman v Claire Steblen [2017] EU:C:2017:256, para 34; Case C-556/14 P Holcim (Romania) SA v European Commission [2016] EU:C:2016:207, para 80; Case C-534/10 P Brookfield New Zealand and Elaris v CPVO [2012] EU:C:2012:813, para 51 and Case T-326/07 Cheminova and other v Commission [2009] EU:T:2009:299, para 228.

${ }^{78}$ Case T-369/03 Arizona Chemical and others v Commission [2005] EU:T:2005:458, para 86.
} 
plaintiff in an action for annulment. The Court held that, as regards the question of admissibility of an action for annulment against an act of regulatory nature with general content, the violation of the individual right arising from the 'general principle' of the duty of care of one party does not make them 'individually concerned' under what is now Article 263 paragraph 4 TFEU, since an unknown number of individuals could claim those individual rights. Although violation of procedural principles protecting individuals would generally have the possibility to evoke individual concern, violation of the duty of care as such, despite being an individual right, was not 'capable of distinguishing that person individually in relation to the measure in question'. ${ }^{79}$ Thus, the General Court classified the duty of care (there referred to as the 'duty of diligence') as a procedural obligation which did not give rise to individual concern. ${ }^{80}$ Given that this statement was easily misunderstood, the Advocate General, in Arizona Chemical as well as in other cases, went on to explain that a lack of standing in annulment procedures does not put into question the individual rights under the duty of care or diligence. In Arizona Chemical, Pfizer, ${ }^{81}$ and Alpharma, ${ }^{82}$ as well as in the subsequent case Agraz ${ }_{3}^{83}$ the General Court thus explicitly clarified the difference between standing and substance-review of an individual right. It stated that standing issues can not preclude plaintiffs from pleading 'an infringement of that obligation by a Community institution, provided that the conditions for the admissibility of an action for annulment or an action for damages are met'. ${ }^{84}$ Accordingly, the duty of care can also be enforced as a principle intended to protect individuals in the context of damages claims under Article 340 TFEU ${ }^{85}$ as recognised in Staelen and Dyson, where the Court reviewed whether the act of an institution may have constituted a sufficiently serious breach of the duty of care as a right designed to protect the individual. 86

\footnotetext{
79 Ibid, para 71.

${ }^{80}$ Ibid, para 86.

${ }^{81}$ Case T-13/99 Pfizer Animal Health v Council [2002] EU:T:2002:209, para 171.

82 Case T-70/99 Alpharma v Council [2002] EU:T:2002:210, para 182.

${ }^{83}$ Case T-285/03 Agraz and Others v Commission [2005] EU:T:2005:109.

${ }^{84}$ Case T-369/03 Arizona Chemical and Others v Commission [2005] EU:T:2005:458, para 88 and Case T-285/03 Agraz and Others $v$ Commission [2005] EU:T:2005:109, paras 49-54.

${ }^{85}$ Case C-337/15 P European Ombudsman v Claire Staelen [2017] EU:C:2017:256, para 41.

86 Ibid. See, for clarification, Case C-44/16 P Dyson v Commission [2017] EU:C:2017:357, para 49, 50. The complexity of cases in the constellation of Staelen nonetheless arises from the fact that not only the violated individual right is a right under the duty of care, but also the question of the breach of duties contains a care-related analysis.
} 
Therefore, the issue regarding regulatory acts, is generally that many individuals have rights arising from the duty of care. They are thus not affected 'individually' in the sense of Article 263 TFEU. Their individual rights can be protected by courts, for example in the context of damages claims and their rights remain 'individual rights or freedoms' recognised by EU law under Article 47 CFR, resulting in the requirements of ensuring effective judicial remedies on the European and Member State levels. ${ }^{87}$

\section{b) The Public Interest in Effective Judicial Review - the German Constitutional Court's Critique}

AG Kokott stated a decade ago in SPCM, that the relation between the two concepts of proportionality and discretion remain 'liable to be misunderstood':88 Without full judicial review probing as to the decision-makers analysis into whether 'there are clearly less oppressive measures available which are equally effective, or if the measures adopted are obviously out of proportion to the aims pursued', ${ }^{89}$ proportionality risks, according to AG Kokott being 'deprived of its practical effect' as one of the Treaty's central criteria of legality of an act. ${ }^{90}$

In this context, the duty of care's basic relevance lies in identifying whether the various factors that need to be balanced in the context of proportionality have been properly analysed and taken into account in decision making - irrespective of whether a decision maker enjoys discretion in adopting the final act or not. ${ }^{91}$

Gamweiler ${ }^{92}$ decided upon a request for a preliminary ruling by the German Constitutional Court (GCC), gives a practical example of this approach. There, the CJEU reviewed the duty of care in the context of its proportionality review of the exercise of very broadly defined discretionary powers of the European Central Bank's (ECB) in matters of monetary policy. ${ }^{93}$

\footnotetext{
${ }^{87}$ See, as an example, the facts underlying Case C-104/13 Olainfarm [2104] EU:C:2014:2316 and the Court's view in paras $35-41$.

88 Case C-558/07 SPCM and others [2009] EU:C:2009:142, Opinion of AG Kokott, paras 73-77.

${ }^{89} \mathrm{Ibid}$. AG Kokott's statements made with respect to legislative acts are equally relevant to the review of non-legislative activity of executive actors.

90 Ibid.

91 See, for example, Case T-333/10 Animal Trade Company (ATC) [2013] EU:T:2013:451, para 103. Here the General Court concludes that violation of the principle of care results in a violation of the principle of proportionality.

92 Case C-62/14 Gauweiler and Others v Deutscher Bundestag (OMT) [2015] EU:C:2015:400.

93 Ibid.
} 
Setting monetary policy requires large quantities of statistical information and economic expertise, two factors which make the exercise of judicial review of the legality of a decision particularly problematic. Accordingly, in Gauweiler a key concept in the review of whether the ECB had complied with its obligations under the principle of proportionality while exercising its broad discretion is was the duty of care, requiring the ECB 'to examine carefully and impartially all the relevant elements of the situation in question' and to document this in an 'adequate statement of the reasons for its decisions'. ${ }^{94}$ Equally in Weiss and Others, the CJEU reviewed the proportionality of the ECB's discretionary decision from the point of the qualitative, quantitative and cognitive elements of the duty of care. .5 Central to the approach is that the nature of monetary policy is that it has potential effects in all walks of life having to deal with money and its availability. It is thus intricately connected with economic effects of monetary policy decisions, as is recognised in the Treaty's definition of secondary goals of EU monetary policy. Thus, the more effects to be taken into account in the more policy considerations, which must include balancing fundamental and fundamental social rights such formulated in the Charter, the broader the legislative, or in the case of the ECB executive discretion is.

Quite strikingly the GCC in in PSPP96 then dismissed this approach as 'incomprehensible', accusing the CJEU of having, by applying this test, allowed ultra vires acts by the ECB. ${ }^{97}$ Two key criticisms stand out: Without further explanation as to the sources of such claim, the GCC claims in PSPP that amongst the factors to be taken into account should have been also direct and indirect 'economic policy effects resulting from the programme'. The GCC in PSPP claims that 'the review of proportionality would be rendered meaningless's violating inter alia

\footnotetext{
94 Ibid, paras 66-69.

95 C-493/17 Weiss and Others ECLI:EU:C:2018:1000 (Grand Chamber), paras 36-42.

${ }^{96}$ German Constitutional Court (Bundesverfassungsgericht) of 5 May 2020 joined cases 2 BvR 859/15, 2 BvR 1651/15, 2 BvR 2006/15, 2 BvR 980/16, para 156. English version at https://www.bundesverfassungsgericht.de/SharedDocs/Entscheidungen/EN/2020/05/rs20200505_2bvr085915e n.html

${ }^{97}$ German Constitutional Court (Bundesverfassungsgericht) of 5 May 2020 joined cases 2 BvR 859/15, 2 BvR 1651/15, 2 BvR 2006/15, 2 BvR 980/16, para 155. Therefore, the GCC held that it was not bound by the CJEU findings of the legality of the ECB action established in Weiss and Others.

98 German Constitutional Court (Bundesverfassungsgericht) of 5 May 2020 PSPP joined cases 2 BvR 859/15, 2 BvR 1651/15, 2 BvR 2006/15, 2 BvR 980/16, paras 133.
} 
standards of an effective judicial protection (Article 47 CFR), ${ }^{99}$ if a court were not to review whether all factors of a decision have been taken into account and, additionally, weighed in an overall assessment by the decision-maker. ${ }^{100}$ This was all the more necessary, the GCC states, where democratic accountability to a parliament is limited by independence of a body such as the ECB and the broad discretion conferred on it. ${ }^{101}$

Interestingly, the notion of full review required under Article $47 \mathrm{CFR}$, has only rarely been addressed by the case law of the CJEU, stating only that with reference to Articles 6(1) and 13 ECHR judicial review should be offered on points of law and fact. ${ }^{102}$ Mere cassation-style review limited to points of law would not suffice. ${ }^{103}$ Full judicial review further requires that judicial review 'examine both the evidence which the determining authority took into account or could have taken into account' if it had properly taken a decision. ${ }^{104}$ Expertise such as technical and scientific specialist knowledge can not, according to the CJEU, be subject to judicial review per se but must be framed in procedural terms. Although therefore the duty of care standards allow for deep and far reaching probing, there seems to be no specific criteria in the principle of effective judicial remedies forcing a court to go further and substitute its assessment for that of an institution constitutionally empowered to assess a situation.

Review, however, will be necessary when the presence of horizontal clauses in EU law, ${ }^{105}$ or the obligation to ensure balancing of fundamental rights positions, will require broader probing into the effects of the case to be done on a case by case assessment. Therefore also the critique of the GCC that the CJEU has been inconsistent in not sufficiently assessing the direct and indirect additional of the monetary policy decision of the ECB whilst generally

99 German Constitutional Court (Bundesverfassungsgericht) of 5 May 2020 PSPP joined cases 2 BvR 859/15, 2 BvR 1651/15, 2 BvR 2006/15, 2 BvR 980/16, para 144.

100 In this article this had been described as reviewing whether quantitatively and qualitatively and cognitively.

101 German Constitutional Court (Bundesverfassungsgericht) of 5 May 2020 PSPP joined cases 2 BvR 859/15, 2 BvR 1651/15, 2 BvR 2006/15, 2 BvR 980/16, PSPP paras 123, 141, 160. In applying this standard, referred to as "wertende Gesamtbetrachtung", the GCC then based its rejection of the CJEU's approach on the fact that the CJEU had not properly balanced secondary economic effects of the ECB's monetary policy acts in the decision on the choice of the legal basis, declaring a measure as an act of monetary policy, or in the exercise of its monetary policy powers. The GCC thus requests from the CJEU a level of review going beyond the assessment of the relevant facts and cognitively basing its judgement on the facts so established as would be the case under the duty of care.

102 C-506/04 Wilson [2006] ECR I-8613, para 62.

103 See e.g. C-69/10 Dioufv Ministre du Travail, de l'Emploi et de l'Immigration ECLI:EU:C:2011:524, paras 56, 57 with reference to C-506/04 Wilson [2006] ECR I-8613, paras 60-62.

104 C-585/16 Alheto EU:C:2018:584 (Grand Chamber), paras 113, 114.

105 Such as e.g. the requirement to ensure high levels of health and environmental protection in Article 114(3) TFEU. 
doing so seem unwarranted. The GCC claims that the CJEU in Weiss and Others deviated from its well-established standards of judicial review including an overall weighing also of indirect and remote aspects which economists might refer to as opportunity costs of measures and their redistributive effects. Yet, despite the GCC claiming that an 'overall assessment' by the CJEU of even fairly remote secondary effects of a measure is standard in various policy areas, ${ }^{106}$ the CJEU case law cited by the GCC to support its argument naturally displays great diversity as to the cut-off point of direct or indirect the effects of the factors to be taken into account can influence the decision. These vary, not surprisingly, according to the factual situation in each case. They however also vary, and that becomes clear from looking at the GCC's claims, according to certain assumptions and economic and political beliefs. ${ }^{107}$

Therefore, the set of values to be pursued by EU law must be carefully be understood as those defined by EU law in the Treaties and EU legalisation. Where the CJEU takes into account legal and de facto effects of a measure, ${ }^{108}$ it finds that where a detrimental effect of a measure on a fundamental right 'is merely an indirect consequence of a policy with which aims of general public interest are pursued' their relevance may 'vary greatly, depending on the economic factors affecting market trends' and thus do not necessarily lead to the annulment of an act. ${ }^{109}$ The CJEU generally refuses to take factors into account that 'do not have any sufficiently direct and specific links' to the rights or freedoms in balance in a proportionality review. ${ }^{110}$ This is not to say, that the CJEU could not be criticized for imposing more strict

106 German Constitutional Court (Bundesverfassungsgericht) of 5 May 2020 PSPP joined cases 2 BvR 859/15, 2 BvR 1651/15, 2 BvR 2006/15, 2 BvR 980/16, paras 146-153.

107 To illustrate this point, I refer to the GCC's considerations as to whether 'economically unviable companies' would be artificially kept afloat. How the idea of economic viability can be detached from market and regulatory conditions is not clear and is not explained by the GCC. Further the GCC requests a proportionality review to consider that some Member States may not implement the 'necessary consolidation and reform measures,' 'increase new borrowing', conduct 'investment programmes' and refrain from pursuing 'a sound budgetary policy'. (German Constitutional Court of 5 May 2020 PSPP joined cases 2 BvR 859/15, 2 BvR 1651/15, 2 BvR 2006/15, 2 BvR 980/16, paras 170, 171). Each display a certain undisclosed but underlying political and economic belief, which could be anchored in constitutional choices but then needs to be counter-balance with other elements including provisions of the Charter and of horizontal provisions in the Treaties. See for a discussion of these dangers: Dariusz Adamski, 'The Faustian bargain. How evolving economic and political beliefs have redefined the European economic constitution', in: Herwig C.H. Hofmann, Katerina Pantazatou and Giovanni Zaccaroni (eds), The Metamorphosis of the European Economic Constitution (Edward Elgar 2019), 25-57.

108 Especially in single market matters (e.g. Case 8/74 Dassonville ECR 1974, I-838, para. 5) and anti-discrimination cases where the discrimination arises not by law but from the factual circumstances of a case (e.g. Case 14/83 Colson and Kamann [1984] ECR I-1892 para. 18; C-300/06 Voßv Land Berlin [2007] ECR I-10592, para. 38).

${ }^{109}$ C-59/83 Biovilac ECLI:EU:C:1984:380, para. 22.

${ }^{110}$ C-435/02 Springer v Zeitungsverlag Niederrhein and Others ECLI:EU:C:2004:552, para. 49 
standards towards the proportionality in the justification of Member State measures limiting EU freedoms than those required of EU institutions and bodies. ${ }^{111}$ But more generally, where the CJEU cannot itself identify which factors will have a sufficiently direct link to the matter, because of necessary scientific or economic expertise, it must review whether the institutions in charge of the question have done so with all due care.

Criticism of the duty of care related approach by the CJEU voiced in the literature, for example, by Mendes is often aimed in a distinctively different direction than the GCC's concerns voiced in PSPP. The fact that the duty of care allows a court to assess 'the plausibility of the decisions in view of the facts that grounded the choices ultimately made'112 in this view renders the CJEU's approach to the principle of care is too fact-based, not sufficiently acknowledging the obligation of decision makers to ultimately serve the public interest and therefore obfuscating whether such forms of control preserve the space of discretion conferred on decision makers by law. ${ }^{113}$ This criticism of the Court's approach appears centred on the decision makers' freedoms to identify approaches in defining a public interest ultimately allowing a more broad freedom to identify what the 'relevant' facts to be taken into account are.

These two positions illustrate quite opposite approaches to identifying the public interest within a system with, on one hand, between a separation of powers inspired respect for discretion and, on the other, a rule of law based concern for effective judicial review of the legality of acts using the principle of proportionality. One position assumes the public interest to be best defended by independent authorities acting in the context of their specific expertise. The other considers that the public interest is best protected by full judicial review of the overall assessment of the relevant factors relevant in a decision. In this sense, the CJEU's identification of the duty of care containing quantitative, qualitative, and cognitive elements under the duty of care point in the direction of a procedural, process-oriented understanding for controlling whether a decision maker is acting in the public interest identified by the legal

\footnotetext{
111 As an example for many: C-110/05 Commission v Italy ECLI:EU:C:2009:66, paras 37-40

112 Joana Mendes, 'Discretion, Care and Public Interests in the EU Administration: Probing the Limits of Law' in Herwig C H Hofmann and Jacques Ziller (eds), Accountability in the EU - The Role of the European Ombudsman (Edward Elgar 2017) 156.

113 Ibid, 156-159.
} 
system. The duty of care, in this view, is a tool to ensure that a decision maker has in fact undertaken to establish the public interest, and that its measures chosen by the decision maker can serve it. On the other hand, it does not attempt to require a full de novo assessment of the factors and their balancing by the reviewing Court, as the GCC in PSPP would seem to require by making the claim that such is a pre-condition for ensuring that effective judicial review under Article $47 \mathrm{CFR}$ and is required under EU law from under Article 19(1) $2^{\text {nd }}$ sentence TEU.

\section{c) The Duty of Care in Codification of Procedures}

The central role of the duty of care as a procedural, information-based approach to ensuring accountability of public action has been reflected not only in attempts at codifying EU administrative law of the past years, but is also reflected in the 2016 Inter-institutional Agreement (IIA) on Better Regulation. The latter contains self-obligations of the Commission to undertake full review of all relevant factors through legislative impact assessment procedures and cost-benefit-analysis, ${ }^{114}$ although such obligations can be hardened in case law, as the above discussed case Poland $v$ EP and Council illustrates. ${ }^{115}$ With regard to non-legislative administrative rule making, the Research Network on EU Administrative Law (ReNEUAL) model rules on EU administrative procedure ${ }^{116}$ outline the basic principles of the duty of care, and take on this principle as lynchpin for regulatory approaches. The explanations to the

114 See the discussion above on the Inter-institutional Agreement between the European Parliament, the Council of the EU and the European Commission of 13 April 2016 on Better Law-Making [2016] OJ L123/1, stating in point 12: 'Impact assessments should cover the existence, scale and consequences of a problem and the question whether or not Union action is needed. They should map out alternative solutions and, where possible, potential short and longterm costs and benefits, assessing the economic, environmental and social impacts in an integrated and balanced way and using both qualitative and quantitative analyses. ... Impact assessments should be based on accurate, objective and complete information and should be proportionate as regards their scope and focus'.

115 See, for a more recent example, the above cited Case C-128/17 Poland v European Parliament and Council [2019] EU:C:2019:194.

116 See, for abstract general administrative rule making procedures, Article II-3 ReNEUAL model rules and, for singlecase decision making, Article III-10 ReNEUAL model rules, linking the principle of investigation with the duty of care. See, for the online 2014 version of the model codes, Herwig C Hofmann and others, 'ReNEUAL Model Rules on EU Administrative Procedure' (reNEUAL, 2014) < https://www.reneual.eu/images/Home/ReNEUALModel_Rules-Compilation_BooksI_VI_2014-09-03.pdf $>$ accessed 16 March 2020 and Paul Craig, Herwig C.H. Hofmann, J-P Schneider, Jacques Ziller (eds.) ReNEUAL Model Rules on EU Administrative Procedure (2017 version of model codes, Oxford University Press 2017). 
model rules state that the role of structured procedures - such as impact assessments for compliance with care-related obligations - is to take into account and weigh relevant information. Finally, with respect to unilateral single-case decision making and decision making by contractual means, the duty of care is used both in the ReNEUAL model rules ${ }^{117}$ as well as in the European Parliament's 2016 draft on a regulation for EU administrative procedures. ${ }^{118}$ In these documents, care is described as a 'counterpart to the principle of investigation' found in national legal orders, and is applied as a tool to set a procedural framework for the exercise of discretionary powers describing the duty of careful investigation as 'a centre-piece of procedural impartiality and fairness'.119

Together these examples show that awareness is rising as to the balancing force of the duty of care in practice. Given the spread of the principle of care in the case law of the CJEU and the increasing references to it in the IIA on Better Regulation and draft legislation, it would appear necessary for legal doctrine to begin to address the underlying concepts more readily.

\section{Outlook}

This article looked into how the duty of care has developed as a procedural principle helping to ensure, on the one hand, accountability and compliance with the rule of law inspired legality concepts and, on the other hand, recognition of the need to respect the delegation of decision making powers and discretion. The overarching question this article is pursuing is whether the duty of care is a principle capable of providing criteria by which the CJEU can undertake the balancing requirements between discretion and proportionality. To do so, the details of the test developed by the CJEU were analysed both from an information-based approach looking at quantitative and qualitative elements of matters to be taken into account - as well

\footnotetext{
117 See Article III-10(1) on the principle of investigation.

118 See 'Proposal for a Regulation of the EP and of the Council for an open, efficient and independent European Union administration' (European Parliament, 6 June 2016) < https:/ /www.europarl.europa.eu/doceo/document/TA-8-20160279_EN.html> accessed 16 March 2020, especially Article 9(1) stating: 'The competent authority shall investigate the case carefully and impartially. It shall take into consideration all relevant factors and gather all necessary information to adopt a decision'.

119 Paul Craig, Herwig C.H. Hofmann, J-P Schneider and Jacques Ziller (eds.) ReNEUAL Model Rules on EU Administrative Procedure (2017 version of model codes, Oxford University Press 2017) 111.
} 
as from a cognitive approach - looking at whether the facts so collected were de facto weighed in decision making and whether they substantiate the content of the final act. It was found that this is a concept applied in single-case decision making, as well as in regulatory and legislative acts. The duty of care is recognised both as an individual right and as an essential procedural requirement in the case law of the CJEU.

In summary, the Court insists on compliance with the duty of care in the context of what might be referred to as a 'deep procedural' review, looking especially at whether the quantity and quality of information used for decision-making was adequate, and whether the latter was actually taken into account in decision-making. Depending on which kind of information is to be taken into account, facts can also be facts presented in the context of scientific expertise, also in the context of economic law and regulation of economic theory. ${ }^{120}$ It is within this latter context that the rule of law-related proportionality aspect can be effectively reviewed without taking away from the policy-related freedom granted by the conferral of discretionary powers on a body or institution. This approach strikes a balance between an empty procedural review and a full review of substance which would risk the exercise of discretionary powers. The approach can be adapted to allow the ex post judicial review of even wide discretionary powers conferred within EU law. Since the latter is not beyond the law, the duty of care offers a legality review by the CJEU, a factor the GCC does not seem to recognise or to appreciate in its blunt PSPP ruling.

This article further found that the spread of the duty of care can be explained by the fact that it does allow balancing for effective judicial review. In the words of the Court of Justice, effective judicial review is one of the essential components of a system under the rule of law, ${ }^{121}$ with respect to the conferral and delegation of discretionary decision-making powers on non-

${ }^{120}$ The notion of facts in the case law of the CJEU was developed with respect to the classification of non-legal theories, including economic theory, as facts in the case law of the CJEU. Thereby, the scope of the matters subject only to limited review has become more circumscribed than in earlier case law. The first wave of cases where economic theory, and its conclusions as well as technical assessments were subject to the same review as facts was in the early 2000s in: max.mobil (Case T-54/99 max.mobil v Commission [2002] EU:T:2002:20), Airtours (Case T-342/99 Airtours v Commission [2002] EU:T:2002:146), Tetra Laval (Case T-5/02 Tetra Laval v Commission [2002] EU:T:2002:264, upheld on appeal in Case C-12/03 P Commission v Tetra Laval [2005] EU:C:2005:87) and also Schneider (Case T-351/03 Schneider Electric v Commission [2007] EU:T:2007:212)

${ }^{121}$ Case C-72/15 Rosneft [2017] EU:C:2017:236, para 73; Case C-362/14 Scbrems I [2015] EU:C:2015:650, para 95 and Case C-562/13 Abdida [2014] EU:C:2014:2453, para 45. 
judiciary bodies. This is the reason for the centrality and ubiquitous nature of duty of carerelated review. Care has thus become a central principle in ensuring effective judicial review within the EU's system, a system highly dependent on the delegation of discretionary powers. Despite the amount of case law on this matter, this article has shown that there are many questions left to explore within academia. Not only are notions of discretionary powers conceptually poorly developed when it comes to EU law, but also key elements of the distinction between the CJEU's powers to investigate facts and its required deference in matters of the discretion of decision makers require further clarification and systematisation. This article is a contribution to the exploration of tools to undertake these distinctions and to overcome conflicts between concepts of judicial review and discretion. Even so, many questions remain unanswered. Further discussions and further conceptual research are needed for the exploration of the duty of care as an individual right. How far does this require carerelated review also in general legislative and non-legislative procedures? How does one distinguish questions of standing from substantive matters in various types of procedures, from actions for annulment to claims for damages? This does not take away from the fact that compliance with the duty of care may also be an essential procedural requirement, and thus the requirements arising from this classification need to be developed regarding legal remedies offered within the EU legal system.

There are several timely aspects of exploring concepts of the duty of care. One was already addressed. It is the GCC's request that the CJEU follow its lead in defining conditions of proportionality review. Another important aspect of the developing duty of care is very different: Due to its nature as an information-related concept of decision-making accountability, research into the duty of care as a legal concept might prove central to discussions about the accountability of automated decision making procedures using artificial intelligence or machine learning tools. Questions of input of information and explainability of outputs might prove to become central elements in holding decision making to account, irrespective of whether decision making is undertaken by humans or machines.

In short, with the duty of care, the CJEU has created an information-based tool which allows it to fine-tune the exercise of judicial accountability. A coherent development of this tool by 
academic research and future case law is an important element for further understanding the review of public action in the EU. This is as important for EU courts as it is for national courts reviewing Member State administrations acting in the scope of EU law. 